\title{
ЕВОЛЮЦІЯ ЛІНГВІСТИЧНИХ ПОГЛЯДІВ НА ПОНЯТТЯ КОНЦЕПТУ ЯК ОДИНИЦІ КОНЦЕПТУАЛЬНОЇ КАРТИНИ СВІТУ
}

Гайдук Н. А. Еволюція лінгвістичних поглядів на поняття концепту як одиниці концептуальної картини світу.

У статті зроблено огляд еволюції лінгвістичних поглядів вітчизняних та зарубіжних мовознавців на поняття концептуальної й мовної картин світу, концепту. Розглянуто основні та неосновні виміри перетину концепцій концептуальної та мовної картин світу. Запропоновано узагальнене трактування понять «концептуальна картина світу», «мовна картина світу», «концепт».

Ключові слова: концептуальна картина світу, мовна картина світу, мовна модель, концепт.

Гайдук Н. А. Эволюция лингвистических взглядов на понятие концепта как единицы концептуальной картины мира.

В статье выполнен обзор эволюции лингвистических взглядов отечественных и зарубежных языковедов на понятие концептуальной и языковой картин мира, концепта. Рассмотрены основные и неосновные точки пересечения концепций концептуальной и языковой картин мира. Предложена обобщенная трактовка понятий «концептуальная картина мира», «языковая картина мира», «концепт».

Ключевые слова: концептуальная картина мира, языковая картина мира, языковая модель, концепт.

Gaiduk N. A. Linguistic evolution of views on the notion of concept as a unit of a conceptual picture of the world.

The article reviews the evolution of linguistic views of national and foreign linguists on the notion of conceptual and linguistic picture of the world, concept. Basic and non-basic conceptual point of intersection of the concepts and language pictures of the world are considered. A generalized interpretation of the notion of «conceptual picture of the world», «language world», «concept» is offered.

Key words: conceptual picture of the world, language picture of the world, language model, concept.

Багатоаспектність концепту, можливості його використання сприяли посиленню уваги мовознавців до утворення та специфіки функціонування названої лінгвістичної категорії, починаючи з кінця XX століття. Проблемами теоретичного обгрунтування картини світу загалом 
та концептів зокрема в різних аспектах займалися такі мовознавці, як Я. Анусевич, Н. Арутюнова, С. Бартмінський, І. Бодуен де Куртене, Г. Брутян, Л. Вайсгербер, А. Вежбицька, Р. Гжегорчикова, В. Звегинцев, Ю. Караулов, О. Кубрякова, А. Кожибський, Д. Лихачов, П. Лозовський, М. Мазуркевич-Бжозовська, В. Маслова, І. Мачкевич, Р. Павільоніс, Г. Палмер, З. Попова, В. Постовалова, Т. Радзісвська, Е. Сепір, Й. Стернін, В. Телія, М. Толстой, Б. Уорф, Т. Цив'ян, Н. Шведова та інші.

Відсутність чіткого тлумачення понять «концепт», «мовна картина світу» та «концептуальна картина світу», наявність неодностайних поглядів на класифікацію концептів свідчать про складність досліджуваного явища. Необхідність грунтовного вивчення концептуальної картини світу загалом й концептів зокрема зумовлюють актуальність дослідження.

Мета дослідження полягає в аналізі лінгвістичних поглядів на концепт як одиницю концептуальної картини світу, з'ясування кваліфікаційних та диференційних ознак мовної та концептуальної картин світу. Основні завдання: простежити еволюції лінгвістичних поглядів на концепт як елемент картини світу, розглянути основні / неосновні виміри перетину концепцій мовної та концептуальної картин світу.

Вивченню мовної картини світу (МКС) присвячено багато досліджень. Проте й досі немає чіткого визначення цього терміна. I саме поняття дослідники називають по-різному: «мовна картина світу», «мовна модель світу». Найчастіше науковці не розмежовують ці терміни та використовують їх як синоніми. Ми послуговуватимемося терміном «мовна картина світу» як таким, що є найбільш сталим у лінгвістичній традиції.

Уперше поняття МКС увів у науковий ужиток німецький лінгвіст Л. Вайсгербер, що так визначав МКС: «це картина, що міститься виключно в мовних структурах, а конкретніше - у структурах мовного змісту, які, як предмети мислення, організовують і впорядковують зовнішній світ і надають узагальнені знання про цей світ» [22, с. 20].

За словами Н. Шведової, «МКС - це вироблене багатовіковим досвідом народу і здійснюване засобами мовної номінації зображення всього існуючого як цілісного i багатоскладового світу <..., що представляє, по-перше, людину, ії матеріальну й духовну життєдіяльність i, по-друге, все те, що ії̈ оточує» [16, с. 15].

В. Телія вважає, що МКС - це «неминучий для мисленнєво-мовної діяльності продукт свідомості, який виникає в результаті взаємодії мислення, дійсності й мови як засобу вираження думок про світ» [10, с. 179].

За думкою Я. Анусевича, «МКС - це, передусім, розуміння та () Н. А. Гайдук, 2015. 
інтерпретація світу з погляду філософії здорового глузду, підсумовування і зіставлення щоденного досвіду і прийнятих <...> у даній комунікативній спільності норм цінностей, способів оцінювання, а також уявлень і установок відносно до дійсності» [18, с. 265].

Р. Гжегорчикова визначає МКС як «поняттєву структуру, закріплену в системі даної мови, у іiі граматичних і лексичних властивостях, що реалізується, як і все в мові, за допомогою текстів (висловлювань)» [20, с. 41].

За визначенням С. Бартмінського, «МКС - закріплені в мові та способах іiі вживання комплексні знання про людину і світ» [19, с. 2].

Ю. Караулов під картиною світу розуміє два різні аспекти розгляду семантики: або загальна, інтегральна картина, сукупність усього мовного змісту, відносно постійна і така, що повільно еволюціонує в часі; або специфічні риси семантики цієї мови, що диференціюють ії від усіх інших мов [5, с. 245]. Слід зазначити, що Ю. Караулов указував на фрагментарний, не завжди завершений характер МКС [5, с. 273]. Причини цієї незавершеності науковець вбачає в іiі значній рухливості, нестійкості. Ми не розділяємо таку думку, оскільки, на наш погляд, МКС, зберігаючи специфічні національні риси, є більш постійною, ніж концептуальна картина світу.

Загальним компонентом даних тлумачень поняття МКС виступає зв’язок з процесом пізнання. Отже, трактуємо МКС як відносно статичну, таку, що користується певними правилами, має оформлений та завершений вигляд і відбиває реальний світ у мовних знаках, виступає сферою експлікації елементів концептуальної картини світу.

Більшість сучасних дослідників не ототожнюють мову і мислення й тому розглядають МКС як частину концептуальної картини світу (ККС), виражену особливим кодом - вербальними засобами. Наразі ККС розглядається як особлива структура, що включає всі людські знання про навколишню дійсність. Терміни «концептуальна картина світу» (ККС), «картина світу» (КС) і «модель світу» (МС) ми, услід за більшістю дослідників, вважатимемо синонімами.

Термін «картина світу» належить до міждисциплінарних понять, а уперше був запропонований фізиками наприкінці XIX - початку XX століття. Спочатку термін використовувався для позначення досягнутих $\mathrm{i}$ доведених наукових результатів. Надалі ця проблема стала центром культурологічних і лінгвосеміотичних робіт.

А. Ейнштейн говорив про те, що людина не може діяти у світі, не уявляючи собі його цілком, у всьому різноманітті: «Людина прагне якимсь 
адекватним чином створити собі просту і зрозумілу картину світу для того, щоб відірватися від світу відчуттів, щоб до певної міри спробувати замінити цей світ створеною таким чином картиною. Цим займаються художник, поет, філософ і природознавець, кожен по-своєму. На цю картину i iї оформлення людина переносить центр тяжіння свого духовного життя, щоб у ній знайти спокій і упевненість, які він не може знайти в занадто тісному запаморочливому кругообігу власного життя» $[17$, с. 136].

У мовознавстві проблема ККС вивчається у відношенні до МКС. Концепція розрізнення МКС і ККС пов'язана з панівною в мовознавстві теорією, відповідно до якої за словом стоїть не поняття, а значення, яке 3 ним не збігається. 3 урахуванням цього МКС відповідає сфері значень, а ККС - сфері понять.

Ю. Караулов вважає, що ККС містить у собі, разом з особливим, найбільш загальний, універсальний погляд на світ. У МКС же втілено найбільш національно специфічне сприйняття дійсності: «Основними елементами, що утворюють мовну модель світу, виступають семантичні поля, тоді як концептуальна модель складається 3 одиниць більш високих рівнів - груп і надпонять, що являють собою «константи свідомості» [5, с. 271].

Г. Брутян, який чітко розмежовував розумову та мовну картини світу, називає ККС «розумовою моделлю світу» і визначає як «знання, зафіксоване в понятійному складі суб'єкта» [3, с. 58].

Р. Павільоніс у роботі «Проблема сенсу: Сучасний логікофункційний аналіз мови» ККС визначається як «безперервно конструйована система інформації (поглядів і знань) про дійсний або можливий світ, яку має в розпорядженні індивід» [9, с. 280]. Основними властивостями такої системи автор вважає континуальність і послідовність введення концептів. Специфіка концептуальної системи пов'язана з процесом розуміння мовних висловів, що репрезентують іiі зміст. Процес розуміння, на думку Р. Павільоніса, «є процесом утворення сенсів, або концептів, який грунтується на перцептивному i концептуальному виділенні об'єкта з середовища інших об'єктів шляхом надання цьому об' єктові певного сенсу, або концепту, як ментальної його репрезентації» [9, с. 283]. Основним принципом побудови концептуальної системи є принцип інтерпретації об'єкта за допомогою сенсів, або концептів. «Така інтерпретація об'єктів у даній системі $\epsilon<\ldots>$ побудовою в ній інформації про певний світ, певну картину світу» [9, с. 206].

Б. Серебреников обгрунтовує розрізнення МКС і ККС постулатом про нетотожність мови і мислення: «Мова і мислення - дві самостійні () Н. А. Гайдук, 2015. 


\section{СТРУКТУРА I СЕМАНТИКА МОВНИХ ОДИНИЦЬ}

сфери, хоч і тісно між собою пов'язані. Відповідно до цього повністю розрізняються дві картини світу - концептуальна і мовна <..> МКС виконує дві основні функції: 1) означування основних елементів концептуальної КС, 2) експлікація засобами мови концептуальної КС» $[10$, с. 6].

В. Касевич також говорить про те, що процес мислення не пов'язаний жорстко 3 мовною формою і тому «переробка інформації (когнітивна діяльність) нормально супроводжується створенням ментальної моделі або використанням уже готової, але самі ці процеси принципово невербалізовні, а їх результат або передумова - ментальна модель - може бути як вербалізовною, так і невербалізовною» [6, с. 13].

В. Постовалова визначає ККС так: «КС $є$ цілісним глобальним образом світу, який є результатом усієї духовної активності людини» $[10$, c. 19]. Т. Цив'ян так пише про ККС: «МС визначається як скорочене $\mathrm{i}$ спрощене відображення всієї суми уявлень у даній традиції, узятих в їх системному і операційному аспектах» $[14$, с. 5]. Лінгвіст підкреслює внутрішню єдність ККС: «У КС співіснує безліч різних кодів, кожен 3 яких має свою певну зону дії, передбачає ієрархічну класифікацію. Увесь цей складний конгломерат на семантичному рівні єдиний, оскільки він описує один і той самий об'єкт - світ - 3 погляду одного і того самого суб'єкта - людини. Змістова єдність означає можливість переходу від одного коду до іншого» [14, с. 6].

Польський мовознавець I. Мачкевич подає визначення у двох аспектах: «КС у генетичному аспекті - це відображення досвіду суб'єкта, який пізнає і який належить до якої-небудь спільноти; у прагматичному аспекті - таке моделювання світу, яке дає змогу людині діяти в ньому. КС є одночасно описом світу, здійсненим з певного погляду, і моделлю світу, що регулює поведінку людей» [21, с. 193]. І. Мачкевич вважає, що «КС, властива даній спільноті, може проявлятися в різних знакових системах: іконографії, широко зрозумілій символіці, обрядах і звичаях, суспільних зв'язках і установах <..> МКС - це частина КС, яка проявляється в мовних даних» [21, с. 194]. При цьому, за І. Мачкевич, у МКС отримують відображення не всі поняття ККС. Це пов'язано з тим, що мова повільніше піддається змінам, чим людський світогляд. У зв'язку з цим I. Мачкевич говорить про неісторичність МКС: «У сучасній мові співіснують кілька пластів, що відповідають різним етапам людського пізнання світу», і тому «МКС можна реконструювати, проте було б методологічною помилкою витягання 3 цієї реконструкції далекосяжних висновків про уявлення i переконання людей, що у даний момент послуговуються цією мовою» [21, с. 196]. Але, з іншого боку, саме через свою інертність МКС здатна 
зберігати і передавати особливий національний погляд на світ.

Слід зазначити, що мовознавці також розділяють ККС на наукову та ненаукову КС. Так, Л. Микешина визначає наукову КС як «предметне знання, що складається з різних форм: фактів, принципів, законів, гіпотез і теорій» $[8$, с. 62]. Ненаукову КС трактують, як «реальні уявлення про світ і людину, властиві членам цієї культурно-історичної спільноти на певному етапі іiі розвитку <..> Це необхідна когнітивна основа адаптації до світу» [6, с. 77-78]. Центр ненаукової КС - людина, іiі сприйняття світу. Наукова КС націлена на пізнання об'єктивної реальності, світу таким, яким він $є$ безвідносно до людини.

Зазначимо також, що деякі дослідники не розрізняють поняття «мовна картина світу» та «концептуальна картина світу», тому, наприклад, польський лінгвіст Є. Бартминський у ролі елементів МКС розглядає «стереотипи, що розуміються у дусі Патнама як колективні, закріплені в мові уявлення про людей і речі, а також явища, риси, що включають, характеризують предмет з боку його якості, функцій, поведінки і т. ін.» $[19$, с. 7]. Тому елементами МКС мовознавець визнає поняття.

Ми, услід за більшістю дослідників, розрізняємо поняття МКС та ККС, визнаємо існування в рамах ККС наукової КС та ненаукової КС, наголошуємо на тісному зв'язку між МКС та ненауковим варіантом КС, вважаємо, що елементи МКС служать засобом експлікації елементів ненаукової КС. Основною структурною одиницею МКС визнаємо, слідом за Л. Вайсгербером, Г. Гиппером, Й. Тріром, Г. Кандлером, Ю. Карауловим та іншими, семантичне поле, елементами ККС концепти. Так, Т. Симашко вважає, що ККС складається 3 денотативних сфер - «безлічі різнорідних відомостей, знань, пов'язаних з тим або іншим фрагментом світу» $[11$, с. 6$]$. У МКС денотативній сфері відповідає денотативний клас - сукупність одиниць мови, що описують ці відомості та знання, - який і є фрагментом МКС.

У сучасній лінгвістиці не існує єдиного визначення концепту. У сучасній науковій літературі термін «концепт» вивчається за різними аспектами, а саме: логіко-філософським (Дж. Кемені, Ч. Пірс, Г. Фреге), власне філософським (Ф. Гаватарі, Ж. Дельоз тощо), лінгвістичним (В. Гак, В. Звегінцев, Л. Резніков, П. Ченоков ), лінгвокультурологічним (А. Вежбицька, Д. Гудков, В. Красних, В. Маслова), когнітивним (В. Дем'янков, О. Кубрякова, З. Попова, Й. Стернін ), психолінгвістичним (О. Залевська, О. Селіванова, В. Старко, Л. Лисиченко, Т. Ковальова) та літературно-культурологічним (Л. Грузберг, Л. Іванова, О. Кагановська, Л. Грузберг). Розмаїття аспектів дослідження свідчить про складність і () Н. А. Гайдук, 2015. 


\section{СТРУКТУРА I СЕМАНТИКА МОВНИХ ОДИНИЦЬ}

неоднозначність самого терміна, і через те залишає питання дефініції дискусійним і відкритим на сьогодні.

Більшістю мовознавців визнається ідеальний характер концепту, що являє собою складну структуру, його значний ступінь абстрактності, зв'язок із культурою та індивідуальною свідомістю. Так, О. Кубрякова трактує концепт таким чином: «Концепт ми трактуємо розширювально, підводячи під це визначення різносубстратктні одиниці оперативної свідомості, якими є уявлення, образи, поняття» [10, с. 143]. Н. Арутюнова визначає концепти як «ключові терміни метамови культури» [1, с. 3]. Ю. Степанов включає до структури концепту поняття, його етимологію, історію, асоціації, пов'язані з поняттям, і його оцінки [12, с. 41].

Л. Чернейко пише про концепти як про особливі абстрактні сутності: «Предмети гіпотетичного, ментального простору є десигнатами особливої категорії абстрактних субстантивів, які у наш час дістали не дуже вдалу назву «культурні концепти»« [15, с. 186].

3. Біжева вважає, що «концепт - це вербалізований символічний образ «ідеального» поняття, що відбиває ментальне уявлення носіїв мови про «об'єкт» дійсності, визначається системою традицій цієї культури, у межах якої він «етимологізує» його внутрішньою формою» [2, с. 65].

Т. Ковальова вказує на соціальну і психологічну суть концептів: «Концепт сприймається як комплексна багатовимірне соціопсихологічне й культурно значиме утворення, яке співвідноситься як з колективною, так і 3 індивідуальною свідомістю, зі сферою науки і мистецтва, побутовою сферою і особистісним середовищем існування суб'єкта» [7, с. 16].

Л. Грузберг також включає до складу концепту вербальну складову, називаючи його «культурно-ментально-мовним утворенням» [4, с. 109]. Крім того, дослідники зазначають, що концепти необхідно вивчати не ізольовано, а враховуючи їх складні взаємозв'язки: «Оскільки абстрактне ім'я членує ідеальний континуум, остільки зону референції імен у свідомості обкреслено, але оскільки цей континуум ідеальний, остільки зміст абстрактних імен взаємопроникний, а зміст одного імені зумовлений змістом інших імен» [15, с. 135].

Отже, наразі в мовознавстві існує безліч достатньо розроблених концепцій ККС та МКС. Загальним елементом усіх цих концепцій $є$ трактування ККС як динамічної складної системи індивідуальних, особистих уявлень, які мають загальноприйняті відображення в мові, тобто утворюють мовну картину світу, яка $є$ статичною, має певні правила, оформлений, завершений вигляд і відбиває реальний світ у мовних знаках. ККС грунтується на спільності законів людського мислення, забезпечує 
можливість адекватного перекладу з однієї мови на іншу, а МКС робить можливим збереження і передачу національної специфіки сприйняття дійсності. Услід за іншими дослідниками, ми визнаємо зв'язок МКС з ККС, а конкретніше, із іï ненауковим варіантом. Структурними одиницями ККС виступають концепти, МКС - семантичні поля.

Не зважаючи на значну кількість наукових розвідок, питання співвідношення ККС та МКС, проблема визначення структурних одиниць мовної та концептуальної КС залишаються актуальними, відкритими та дискусійними та потребують подальших досліджень.

\section{Література}

1. Арутюнова Н. Д. От редактора / Н. Д. Арутюнова // Логический анализ языка : Культурные концепты / отв. ред. Н. Д. Арутюнова. - М., 1991. - С. 3-4.

2. Бижева 3. Х. Культурные концепты в адыгской языковой картине мира : дис. ... д-ра филол. наук / З. Х. Бижева. - Нальчик, 1999.

3. Брутян Г. А. Языковая картина мира и ее роль в познании / Г. А. Брутян // Методологические проблемы анализа языка. - Ереван : Изд-во АН Арм. ССР, 1976. C. $57-62$.

4. Грузберг Л. А. Концепт как культурно-ментально-языковое образование / Л. А. Грузберг // Изменяющийся языковой мир : Тезисы докладов междунар. науч. конференции. - Пермь, 200 1. - С. 109-111.

5. Караулов Ю. Н. Общая и русская идеография / Ю. Н. Караулов. - М. : Наука, 1976. $-355 \mathrm{c}$.

6. Касевич В. Б. Языковые структуры и когнитивная деятельность / В. Б. Касевич // Язык и когнитивная деятельность : сб. науч. тр. - М. : Наука, 1989. - С. 5-21.

7. Ковалева Т. Ю. О содержательных контекстах понятия «концепт»/ Т. Ю. Ковалева // Язык. Человек. Картина мира : Материалы Всероссийской научной конференции ; под ред. М. П. Одинцовой. - Ч. 1 - Омск, 2000. - С. 16-18.

8. Микешина Л. А. Научная картина мира как мировоззренческая форма знания / Л. А. Микешина // Научная картина мира. Логико-гносеологический аспект : сб. научн. тр. - К. : Наук, думка, 1983. - С. 62-79.

9. Павиленис Р. И. Проблема смысла: Современный логико-функциональный анализ языка / Р. И. Павиленис. - М. : Мысль, 1983. - 286 с.

10. Роль человеческого фактора в языке. Язык и картина мира / [отв. ред. Б. А. Серебренников]. - М. : Наука, 1988. - 212 с.

11. Симашко Т. В. Денотативный класс как основа описания фрагмента языковой картины мира : автореф. дис. ... д-ра филол. наук / Т. В. Симашко. - Екатеринбург, 1999.

12. Степанов Ю. С. Константы. Словарь русской культуры. Опыт исследования / Ю. С. Степанов. - М. : Языки рус. культуры, 1997. - 824 с.

13. Телия В.Н. Коннотативный аспект семантики номинативных единиц / В. Н. Телия. - М. : Наука, 1986. - 141 с.

14. Цивьян Т. В. Лингвистические основы балканской модели мира / Т. В. Цивьян. - М. : Наука, 1990. -203 с.

15. Чернейко Л. О. Лингвофилософский анализ абстрактного имени / () Н. А. Гайдук, 2015. 
Л. О. Чернейко. - М. : Изд-во МГУ, 1997. - 320 с.

16. Шведова Н. Ю. Теоретические результаты, полученные в работе над русским семантическим словарем / Н. Ю. Шведова // Вопросы языкознания. - 1999. - №1. 1999. - С. 3-17.

17. Эйнштейн А. Влияние Максвелла на развитие представлений о физической реальности / А. Эйнштейн // Собр. научн. тр. - Т. 2. - М. : Наука, 1967. - 878 с.

18. Anusiewicz J. Problematyka językowego obrazu swiata w poglądach niektorych jęyzkoznawcow i filozofow niemieckich XX wieku / J. Anusiewicz // Językowy obraz swiata ; pod red. J. Bartminskiego. - Lublin : UMCS, 1999. - S. 261-291.

19. Bartminski J. O językowym obrazie swiata Polakow konca XX wieku / J. Bartminski // Рукопись, 2001. - 30 c.

20. Grzegorczykowa R. Pojącie językowego obrazu swiata / R. Grzegorczykowa // Językowy obraz swiata ; pod red. J. Bartminskiego. - Lublin : UMCS, 1999. - S. 39-47.

21. Mackiewicz J. Kategoryzacja a językowy obraz swiata / J. Mackiewicz // Językowy obraz swiata ; pod red. J. Bartminskiego. - Lublin : UMCS, 1999 - S. 47-57.

22. Weisgerber L. Vom Weltbild der deutschen Sprache / L. Weisgerber. - Düsseldorf, 1950. Стаття надійшла до редакиії 03.09.2015 p. 